Saeculum Christianum

vol. XXIII (2016)

pp. $93-101$

\author{
ANNA GEUSIUK \\ WNHiS UKSW, Warszawa
}

\title{
EDUCATION OF GIRLS IN THE 14TH CENTURY ACCORDING TO FRANCESCO DA BARBERINO ${ }^{1}$
}

The purpose of this paper is to present the virtues that girls from families of high social status, and later young women of a marriageable age, must possess, according to the work of Francesco di Neri da Barberino titled Reggimento e costumi di donne. This pamphlet, written in the 14th century by an Italian notary and poet, is one of the few medieval treatises addressed exclusively to women. In fact, contemporary writers addressed their works predominantly to men because they were considered more intelligent than women and they had better chances of receiving a good education. Raising children at that time was more in the hands of men, while the task of educating girls was left to their mothers or to convents.

The daughter's future depended on her parents, especially her father. In fact, the decision, whether the child should embrace a religious life or become a wife, was solely theirs to make. Having made the decision, the parents sent the girl whose fate was tied to the church to a convent, where she learned how to become a nun. As it will be discussed in more detail later, the girl who was to marry was instead sent to a convent school or the court of a noblewoman, where she learned how to be a good wife. If the other options were not available, she would stay at home ${ }^{2}$.

It should be noted, however, that female education in the Middle Ages did not closely resemble male education, as girls were not taught the trivium and quadrivium subjects. Husbands did not expect their wives to have this kind of knowledge. Admittedly, men were not overly concerned with women's education, often considering it a waste of time and money. They also saw it as a potential threat, fearing misunderstandings or deception - if a woman could read and write then she could read novels or texts on theology, philosophy or others subjects that she might then misinterpret. She could also write love letters to her beloved, unbeknownst to her father or husband. ${ }^{3}$ It is no surprise then that most men thought it safer to let their daughters learn things such as running the household, looking after their younger siblings, sewing or spinning, without ever learning to read and write.

\footnotetext{
Cf. E. Pasquini, Francesco da Barberino w Dizionario Biografico degli Italiani, Catanzaro 1997, pp. 686-691; R. Ortiz, Francesco da Barberino e la lettura didattica neolatina, Rome 1948, pp. 19-24.

2 Cf. E. Power, Donne nel medioevo, M.M. Postan ed., Milan 19994, p. 75, P. Aries, Padri e figli nell'Europa medioevale e moderna, vol. 2, Bari 1976, p. 430.

3 Cf. E. Power, L'educazione delle donne in: Né Eva né Maria. Condizione femminile e immagine della donna nel Medioevo, M. Pereira ed., Zanichelli, Bolonia 1981, p. 103.
} 
Before presenting Francesco da Barberino's thoughts on raising a girl, when she begins to discern between what is good and what is evil and feel ashamed ${ }^{4}$, and later when it is time to wed $a \mathrm{man}^{5}$, it is necessary to briefly discuss female education. Furthermore, other educational works of the time, addressed to both women and men, also must be mentioned in the discussion, since Francesco da Barberino's pamphlet was not the only text of this kind written in the Middle Ages.

\section{Female education and educational treatises}

Discussing medieval female education from a modern perspective is a fairly complex task. Due to the scarcity of medieval texts, it is difficult to determine with certainty how women's education was presented at that time. Angela Giallongo, an Italian scholar, in her book on education in the Middle Ages, pointed out that girls are virtually absent in the history of education. ${ }^{6}$ However, two models of medieval female education can be distinguished with the use of modern sources. The first is concerned with teaching etiquette, while the second with instructing women on taking care of their husbands. ${ }^{\text {? }}$

At the heart of social education (etiquette) was the teaching of good manners. Women who wanted to play an outstanding role in society (or had to do so), had to be well-versed in the rules of polite social intercourse. However, in addition to etiquette, they also learned to read, tell stories, go hunting, and play chess or other board games, among other things ${ }^{8}$. Robert de Blois, a 13th-century French poet, praised the skills of a lady in one of his poems:

She carried and flew a falcon, tercel, and a hawk,

played chess and backgammon well,

read stories and told them,

and sung songs. Everything a well-bred lady should know

she knew, she lacked nothing ${ }^{9}$

The second educational model was concerned with the conduct of the wife towards her husband, her household chores, religious duties, and more ${ }^{10}$. A number of texts were written on the topic, such as Le Ménagier de Paris, a 14th-century French guidebook, the poem Come una buona moglie insegna alla figlia ${ }^{11}$, or an anonymous English poem, probably written around the same time, titled What the Goodwife taught her daughter ${ }^{12}$, which illustrate what expectations husbands had and what virtues wives were expected to have.

\footnotetext{
4 Francesco da Barberino, Reggimento e costumi di donne, G.E. Sansone ed., Rome 1995, p. 6.

5 Ibidem.

6 A. Giallongo, Il bambino medievale. Educazione ed infanzia nel Medioevo, Bari 1997, p. 26.

Cf. E. Power, L'educazione delle donne, ibidem, pp. 102-103.

Cf. Idem, Donne nel medioevo, ibidem, p. 72.

Cf. E. Power, Donne nel medioevo, ibidem, p. 72.

10 Cf. ibidem pp. 72-73.

11 Menager de Paris, The good wife's guide, G.L. Greco, Ch. M. Rose translated with Critical Introduction, Cornell University 2009.

12 Anne of France, Come la buona madre insegnò alla figlia w C. Xodo Cegolon, Lo specchio di Margherita, per una storia dell'educazione femminile nel Basso Medioevo, C.L.E.U.P., Padua 1988, pp. 130-137.
} 
The texts written in the Middle Ages that survived to modern times show that there was no uniform concept of teaching women how read and write. Some writers, such as Francesco da Barberino, did indeed believe that only girls from noble houses should know how to read and write. According to the poet, women could find use for these skills when looking after their properties. On the other hand, Francesco da Barberino doubted whether such an education was necessary for the daughters of simple gentlemen, and he argued that it certainly should not be allowed to the daughters of merchants and artisans. ${ }^{13}$ As for reading, Anne of France in her book Lessons for my Daughter advises women to read books written by certain authors: To know more and live a life of devotion, I recommend that you read the book by St. Louis, the one by St. Peter of Luxembourg, the Summa Theologiae, The Clock of Wisdom or other texts on the lives of saints. The writings of philosophers and ancient sages are also worthy or your attention. Their teachings contain verities and examples to follow, as philosophy is the most honest of occupations. ${ }^{14} \mathrm{~A}$ different approach can be found in Le Ménagier de Paris and in the works of Christine de Pisan, which recommend teaching all women how to read and write ${ }^{15}$. The Book of the Knight of the Tower present a similar view, arguing that women should know how to read to be able to read the Holy Scriptures ${ }^{16}$. On the other hand, Paolo da Certaldo told a father that it is not good for a woman to know how to read, if he does not plan to send her to a convent ${ }^{17}$. Later writers, such as Philip of Navarre, argued that all women should be prohibited from receiving an education ${ }^{18}$.

With regard to the education of girls from noble families, there were three ways of learning that were considered suitable for their status. They could learn in convent schools, on the royal court or the court of a great noblewoman or at home ${ }^{19}$. The choice depended largely on the family's financial situation. Not much can be said about teaching in convent schools, as there are no surviving records that could shed light on the subjects being taught there. The girls surely learned to read and write the catechism and Latin, at least until the 14th century $^{20}$, but nothing else is known. As Eileen Power points out, the intellectual level in many convents was high in the first centuries of the Middle Ages, but it declined over time. From the 14th century on, as it has already been mentioned earlier in this paper, Latin was no longer taught, and from the 15 th century teaching of French was abandoned ${ }^{21}$. Furthermore, education in convent schools was expensive even for noble families and not all parents could afford to send their daughters there, especially if they we were raising more than one girl.

A second way to learn subjects suitable for the daughters of noble houses was to send them to the royal court or to the court of a noblewoman. Even Anne of France in her Lessons for my Daughter advises her daughter to serve as lady or noblewoman who enjoys a good

\footnotetext{
13 Cf. E. Power, Donne nel medioevo, ibidem, p. 74; Idem, L'educazione delle donne, ibidem, p. 103.

14 Anne of France, Insegnamenti alla figlia Susanna, ibidem, p. 89.

15 Cf. E. Power, Donne nel medioevo, ibidem, p. 74.

16 G. Tour De La Landry, The Book of the Knight of La Tour-Landry: Compiled for the Instruction of His Daughters, London 1868, p. 117.

17 Paolo da Certaldo, Libro di buoni costumi, A. Schiaffini ed., Florence 1945, p. 27.

18 Cf. E. Power, Donne nel medioevo, ibidem, p. 74.

19 Cf. Idem, p. 75; P. Aries, Padri e figli, ibidem, p. 430.

20 Cf. Ibidem, pp. 76-77.

21 Cf. Ibidem, pp. 76-77.
} 
reputation, is not capricious and has common sense $e^{22}$. The girls spent many hours in the company of a noblewoman and by observing and serving her they would learn everything that could be useful to them in the future. Moreover, life on the court presented more opportunities to meet influential men and marry a good match. In fact, the parents that sent their daughters to a court hoped that, apart from learning the etiquette and other things, the girls would also find a suitable husband.

The third way, and perhaps the most common one, was for the girls to stay at home and learn from their mother and, if she had any brothers, from the tutor, hired by their father for them. Sometimes, if the father agreed, the girls were also taught by the tutor in charge of educating the boys. This way the girls learned from their mother what they needed to know and then they spent a few hours learning together with their brothers the subjects taught by the tutor.

To reiterate, it was not generally expected of noble girls to know the subjects included in trivium or quadrivium, but rather to know how to behave in polite society, play board games, and tell stories, among other things. Obviously, this cannot be generalized to all women living at that time because there were women who had received a good education, such as Dhuoda, the author of a handbook written for her son Guglielmo; Trota a physician from Salerno; Héloïse, the beloved of Peter Abelard; or Christine de Pisan, a prolific writer. It is immediately apparent that only the names of secular women have been listed, and those of nuns have been omitted. When the girls joined a convent, they received an education deemed adequate for a nun and their parents had little say in this matter.

As for the education of girls who were to marry in the future, they learned the subjects suitable to their social status. Naturally, princesses learned different things than, for example, daughters of a merchant. In contrast, there was not much difference in the subjects and rules of courteous conduct taught to girls from noble families. Even Francesco da Barberino emphasized the fact that the same conduct was expected of daughters of a baron or a count and those of the emperor or a king ${ }^{23}$. Furthermore, society was more demanding of girls from noble families than of those from merchant or peasant families. Girls from lower social classes enjoyed greater freedom, while those born in noble families were treated more strictly. This difference is evident in Francesco da Barberino's work, who in his Reggimento e costumi di donne addresses girls, differentiating among them not only according to their age but also their milieu. The author writes about girls, damsels, married women, widows, nuns, maids, servants, nurses (nannies), slaves, and women working in various professions. He also distinguishes between them according to their social status, starting with the daughters of the emperor, of a crowned king, baron, knight, merchant etc.

At this point, it should be emphasized that the work of Francesco da Barberino was not the only educational text written in the Middle Ages; however, what distinguishes Reggimento from other similar works from that period is the fact that the brochure is addressed exclusively to female recipients. Most educational texts were addressed to men, as the author of the Reggimento notes in the preface: Francesco, I recently spoke with Honesty and, at the request

\footnotetext{
22 Anne of France, Insegnamenti alla figlia Susanna, ibidem, p. 91.

23 Cf. Francesco da Barberino, Reggimento, ibidem, p. 23.
} 
of many other women, I complained to her that there were many who had written books on courteous conduct of men but not of women ${ }^{24}$.

Other texts dealing with court etiquette include Libro di buoni costumi by Paolo da Certaldo, the Livre des trois vertus by Christine de Pisan, and De quinquaginta curialitatibus ad men by Bonvesin da Riva. There was also another text titled Della Cortesia by Tommasino de Cerchiari, but it was, unfortunately, lost. One of the most famous Italian 15th-century preachers also spoke of the conduct and education of young women in his sermons: Bernardino of Siena ${ }^{25}$. In addition to texts on good manners, a number of texts containing guidelines for marriage survived to this day, such as the Ménagier de Paris, the poem Come una buona moglie insegna alla figlia, and the anonymous English text titled What the Goodwife Taught her Daughter.

\section{REGGIMENTO AND EDUCATION}

\subsection{The girl}

Francesco da Barberino's Reggimento e costumi di donne is written in both verse and prose and composed of a preface and twenty chapters. The first chapter is addressed to girls at an age when they begin to feel embarrassed and blush ${ }^{26}$. At the beginning, the author refers to girls from families of high social status, such as the daughters of the emperor and kings, then moving on to daughters of counts, barons, knights, physicians, merchants etc.

Societal expectations of the daughters of the emperor or kings, counts, barons and knights were remarkably high. They were expected to conduct themselves impeccably. They had to be well educated, follow the etiquette, and know how to skillfully maneuver any social situation. Given the high expectations, girls learned good manners and proper conduct from their mothers, nurses, and teachers from an early age. To avoid any improper conduct, it was deemed necessary for the girls to constantly be under the watchful eye of their mothers or the other women. Francesco da Barberino also argued that young women should be raised in company of other women, especially their mothers ${ }^{27}$.

With respect to the social life of girls of that age, they were kept away from people and especially from men. Bernardino, the greatest Sienese preacher, used to say that girls should stay at home because it better when they are locked $u p^{28}$ because this allows them to dedicate themselves to reading de le cose Sante e buone ${ }^{29}$, if they knew how to read, or to useful work. Girls could meet knights when the parents' guests came to visit, but this only happened if they were invited by her father, mother or someone from the house, and they always had to be accompanied by their nurse or teacher ${ }^{30}$. Girls could not stay alone with

\footnotetext{
24 Ibidem, p. 1.

25 Bernardino of Siena, Le prediche volgari: quaresimale fiorentino 1424, C. Cannarozzi ed., vol. 2, A. Pacinotti, Pistoia 1934; idem, Le prediche volgari tom 3, Florence 1940; idem, Le prediche volgari vol. 2, Florence 1958; idem, Prediche volgari sul campo di Siena 1427, C. Delcorno ed., vol. 2, Milan 1989.

26 Cf. Francesco da Barberino, Reggimento, ibidem, p. 9

27 Cf. Ibidem, p. 9.

28 Bernardino of Siena, Prediche volgari sul Campo di Siena 1427, C. Delcorno ed., vol. 2, Rusconi, Milan 1989, p. 862 .

29 Ibidem, p. 862.

30 Cf. Francesco da Barberino, Reggimento, ibid, p. 10.
} 
men, without the company of other women. They also had to be careful not to look at men because by staring at a man they could easily delude him into thinking that he was loved by her and that he was obliged to woo her ${ }^{31}$.

Furthermore, when girls were among other people, they had to know when to speak and when to remain silent: (...) one should not keep silent, when others do not speak, so that they do not say: She does not speak, for she is mute ${ }^{32}$. Girls had to strike a balance between speaking and remaining silent, but they were perceived more favorably when they listened more than they spoke. Another thing to avoid was gesturing during talking. The poet stressed that when a girl is asked something or invited into a conversation, she should answer in moderation and speak in a soft tone of voice, with her hands and other limbs remaining still ${ }^{33}$. This view was shared by Bernardino of Siena. In one of his sermons addressing parents, he advised them to teach their daughters to never be a "speaker" 34 and to remember the proverb who talks too much, errs more often ${ }^{35}$. Anne of France also recommended her daughter to speak and observe in moderation and not be the first or the last person in a conversation ${ }^{36}$.

With regards to table manners, Francesco da Barberino taught that girls must always be orderly and courteous ${ }^{37}$. The author of Reggimento stressed that it was not appropriate for girls to drink because as much as it is inappropriate for a man to get drunk, it is much too discourteous for a woman to do $\mathrm{so}^{38}$. Another rule concerned conversation during meals. Girls should not speak excessively or rest their heads on their hands and if a girl speaks little, this is the place where she should speak even less. She should never rest her head on her hands, nor throw them around her teacher's neck, if she is not ill ${ }^{39}$.

Francesco da Barberino saw nothing wrong in teaching girls singing and dancing. In fact, he allowed girls to sing when they were in the company of other people, but only at the explicit request of a gentleman, their mother or other companions. However, girls did not have to grant such requests immediately because it was considered polite conduct if they resisted them a little ${ }^{40}$. Moreover, when performing a song, a girl should be facing her audience, but look down rather than at the people sitting in the chamber ${ }^{41}$. The poet assures us that such a performance, called chamber singing is very popular and it reaches out into the hearts of the listeners ${ }^{42}$.

\footnotetext{
Ibidem, p. 10.

Ibidem.

Ibidem.

4 Bernardino of Siena, Prediche volgari, ibidem, vol. 2, p. 972

Ibidem, p. 874.

36 Anne of France, Insegnamenti alla figlia Susanna, ibidem, p. 100.

37 Cf. Francesco da Barberino, Reggimento, ibidem, p. 11.

8 Ibidem.

39 Ibidem.

40 Ibidem.

41 Ibidem.

42 Ibidem.
} 
Francesco da Barberino allowed girls to dance, but they had to do it decently ${ }^{43}$ and without too much jumping to avoid showing any leg in dance - something that happened to Sensonia, the daughter of Guglielmo da Folcalchieri ${ }^{44}$.

Francesco da Barberino demanded that girls be modest even in tears and laughter. Girls were allowed to cry, but their weeping must have been silent ${ }^{45}$. When it comes to laughter, it was not in good taste for a girl to laugh in such a way as to show teeth: do not shout Ah! Ah! or anything in a similar voice, nor make noises that would make you show your teeth, that is impolite; laugh, but without making any noise ${ }^{46}$. Anne of France had a similar view of laughter. She taught her daughter Suzanne not to laugh too much, whatever the cause, because it is very inappropriate, especially for young women of noble houses, who, in all circumstances, must have more moderate, polite, and confident ways than others ${ }^{47}$.

Francesco da Barberino saw nothing wrong in adornments, saying: That a woman puts effort into her looks, wearing elegant attire and a garland, is worthy of praise. A woman should be graceful and feminine ${ }^{48}$. But girls had to be wary of not adorning themselves too much. They had to keep in mind that nature itself is the best adornment:

I admire the beauty in women that lasts,

for it is thanks to nature itself ${ }^{9}$.

Writings of Bernardino of Siena and Anne of France shed more light on the way girls dressed and adorned themselves. Bernardino considered it a sin to have too many items of clothing $^{50}$ and insisted that modest clothing testifies to the young woman's decency ${ }^{51}$. Anne of France discussed this topic in more depth and insisted on wearing elegant and clean clothes. She advised Suzanne to always choose your attire with as much care as you can and dress appropriately ${ }^{52}$ She considered it inappropriate and highly discourteous for a girl or noblewoman to be dressed elegantly but carelessly ${ }^{53}$. Anne of France also insisted on not wearing brash clothes, or clothes that are either too tight or too loose $e^{54}$.

Furthermore, according to Francesco da Barberino, girls going to church for mass always had to be accompanied and conduct themselves modestly. And if she goes to church with her mother, she gradually learns how to be decent and polite and how to pray from memory, as does her mother and other women; always following the example given by her nurse or the nurse's husband, as he is admirable and decent ${ }^{55}$.

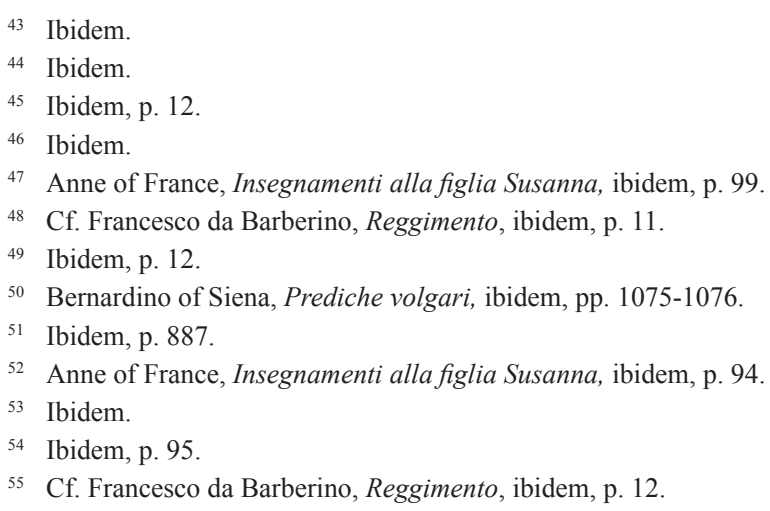


With regard to teaching girls to read and write, the author of the Reggimento claims that: And it seems to me that, considering her status, a girl should partake in reading and writing lessons at this time, so that she can manage her properties, if she is to remain on them, for it is common wisdom that additional knowledge acquired through reading can help in such matters $^{56}$. The poet considered reading a beneficial ability because it could prove to be useful in adult life but suggested that it should be taught by a woman or a trusted person ${ }^{57}$.

\subsection{Young women}

The second chapter of the Reggimento is addressed to girls of marriageable age. They had to remember everything they had learned so far and be careful not to tarnish their reputation.

One of the most important things for the poet was to keep the girls of this age away from windows, balconies, cloisters, and public places $^{58}$. As already pointed out, girls were to be kept locked indoors even when they were younger, Francesco da Barberino compared a girl to a treasure:

and every rare possession,

is precious, as the wise sage once said ${ }^{59}$.

Bernardino expressed a similar sentiment, when he warned his parents to keep their daughters away from windows because the girls might be expecting to meet someone and chat, hear songs or to watch boys playing ball ${ }^{60}$. This admonition to stay away from windows and doors shows that this was a very frequent vice among women of that time. To resist the temptation, women always had to be busy. The work of young women in homes was always well regarded, but its type depended on the social status of the family. According to Francesco da Barberino, girls from noble houses should possess useful practical skills, such as sewing and embroidering, because one can never be sure of one's fortune ${ }^{61}$.

When the girls happened to leave the house, the poet warned them to behave appropriately, to walk with small steps in front of their mother, and not to look around ${ }^{62}$. Still, Francesco da Barberino argued that girls of marriageable age should remain indoors in order not to be seen by young men and to avoid any contact with them. The poet emphasized that for a girl of that age it is inappropriate to go to church $^{63}$. When the rest of the family went for mass, the girl was to stay in her rooms and should she desire to read in her library, let her state her intent ${ }^{64}$. Francesco da Barberino was, however, against long prayers and meditations, adding that: (...) well, I do believe that for a girl to pray too much is not appropriate, as it is better to pray less and not as fervently ${ }^{65}$.

When girls were present at a banquet or in places where there were other people, they could not, according to the poet, smile or stare at other people66. In fact, should, by the will

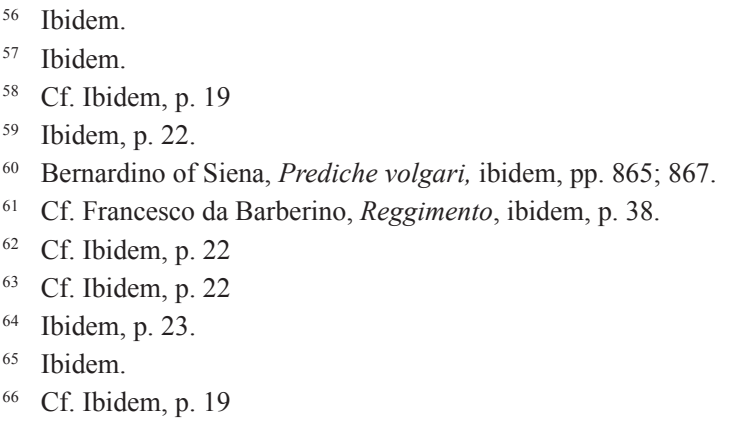


of her father or mother, a girl be allowed to come and stay among other people - whether indoors or in a garden, or perhaps on a ship, as such is the case at some times, or, her eyes should not express too much excitement ${ }^{67}$. For their own safety, girls always had to be in the company of either their mother or their teachers ${ }^{68}$ and speak only when permission was given $^{69}$. The only place where a girl could talk quietly was her room: there she can spend her time, using beautiful words and speaking more often ${ }^{70}$.

With regard to music, Francesco da Barberino allowed girls to learn how to play on a beautiful and appropriate instrument, but they had to learn it from a woman who, if she is not a member of the girl's family or the court where the girl is being raised, should be supervised by one of the other teachers ${ }^{71}$.

\section{Conclusions}

This paper briefly describes the education of girls who lived in the Middle Ages. The places where girls from noble houses could receive an education suitable to their social status were divided into three categories. Firstly, convent schools were mentioned, then the royal court or the court of a respected noblewoman, and lastly their family house. The surviving writings allow us to learn what virtues were expected from noble girls who were to be wed.

Reggimento e costumi di donne, written by Francesco da Barberino, is one of the few medieval texts on the proper conduct of women. The poet discusses the rules of polite conduct for girls and young women of marriageable age coming from a family of high social status. Thanks to his writings, we can learn which virtues the girls had to have, what type of conduct was well regarded, and what was not was not accepted by the society of the time.

\section{Education of girls in the 14th century according to Francesco da Barberino Summary}

Francesco da Barberino is the author of one of the few female etiquette texts written in the Middle Ages. In this period, a number of texts on court etiquette had been written but the most of them were addressed to the male reader and only few of them were written specifically for women.

In his works, Francesco da Barberino shows the rules of court etiquette appropriate for a girl from a family of high social status the age of marriage. Thanks to his work, we have knowledge on which virtues were appreciated, what was allowed, and what type of conduct was not accepted by the society of the time.

Keywords: Francesco da Barberino, court conduct, Reggimento, Middle Ages, education

About the author: dr Anna Głusiuk, assistant professor at the department of Medieval History, Faculty of History and Social Sciences. Academic interests: medieval literature, status and role of women in the Middle Ages.

\footnotetext{
67 Ibidem, p. 20.

68 Cf. Ibidem, p. 20

69 Cf. Ibidem.

70 Ibidem.

71 Ibidem.
} 